Journal of Social Sciences (COES\&RJ-JSS)

ISSN (E): 2305-9249 ISSN (P): 2305-9494

Publisher: Centre of Excellence for Scientific \& Research Journalism, COES\&RJ LLC

Online Publication Date: $1^{\text {st }}$ April 2018

Online Issue: Volume 7, Number 2, April 2018

https://doi.org/10.25255/jss.2018.7.2.139.156

\title{
Reviewing the Literature of the Effect of Talent Management on Organizational Effectiveness
}

\author{
Ra'ed Masa'deh*, Haneen Yassin**, Yasar Shatnawi***, Bader Obeidat****
}

Abstract:

Talent management is a challenging ease concept in the business field, that has started to widespread among organizations locally and internationally, however, this aspect of management is completely related to the human being nature, therefore, a great cautious need to be considered when applying it through an organization especially in service-providing organizations. The purpose of this paper is to reviewing the literature and the impact of talent management on organizational effectiveness.

\section{Keywords:}

Talent management, Organizational effectiveness.

\section{Citation:}

Masa'deh, Ra'ed; Yassin, Haneen; Shatnawi, Yasar; Obeidat, Badar (2018); Reviewing the Literature of the Effect of Talent Management on Organizational Effectiveness; Journal of Social Sciences (COES\&RJ-JSS), Vol.7, No.2, pp:139-156; https://doi.org/10.25255/jss.2018.7.2.139.156.

* Management Information Systems Department, The School of Business, The University of Jordan, r.masadeh@ju.edu.jo https://orcid.org/0000-0002-9070-3732

** Department of Business Management, The School of Business, The University of Jordan, haneenyassin@yahoo.com

*** Department of Business Management, The University of Jordan, Aqaba Branch, Jordan, yas.shatnawi@ju.edu.jo

**** Department of Business Management, The School of Business, The University of Jordan, b.obeidat@ju.edu.jo 


\section{Introduction}

The interest in talent management theme has been grown rapidly over the last years, changes in business environments have enforced organizations to pursue for employees with high potentials or excellent abilities (talented employees). Talent management is defined by Thunnissen and Buttiens (2017) as "the systematic attraction, identification, development, engagement/retention, and deployment of talents." Human resource management has the responsibility to manifest the organization's needs for talents under constraint of time and budget (Canedo et al., 2017). It's worth to mention, technology development have role in inducing new innovation ways to evaluate the talent in work (Chamorro-Premuzic et al., 2017).

Recently, business pay attention and work to keep the optimum human resource as they recognize the human capital role to grant a competitive position for the organization, that is directly poured into leadership effectiveness (Sumardi, 2014). To make best advantage of the available human resources, the main reliance is on practicing an effective talent management that leads to releasing the potentials of the targeted human resource who can face and handle challenges effectively. Talent management is lately the biggest concern of the corporate human resource directing and coaching, and it is beneficial and important for organizations where their consumers and customers have highly sophisticated needs and least mistakes, at the same time, who seek to deliver the maximum potential share value to the shareholders (Fapohunda, 2014). The ability of the organization to attain its goals is based on achieving a competitive advantage (Schuler and Jackson, 2014). The linkage between talent management and business success has been noticed by many studies (e.g. Mathew (2015) and Fogarassy et al. (2017)).Currently, and due to the fast pace, consuming, and changing world, some researchers stressed on making the organizational effectiveness an ongoing and sustained process, thus having an upward performance level (Mohrman and Lawler, 2014).

Talent management was fundamentally designed to improve the process of recruiting and developing people with the required skills and aptitude to meet the set of organizational needs. Talent management comprises recruiting, selection, on boarding, mentoring, performance management, career development, leadership development, replacement planning, career planning, recognition, and reward (Heinen and O'Neill, 2004). The ongoing competition among businesses and the lack of availability of highly talented and skilled employees impose finding and retaining talented employees as a top priority for organizations (Fegley, 2006), and in order to attract and retain the best talent anywhere in the world, an organization must have strong and positive talent management strategies (Brewster and Suutari, 2005). Inside the organization, the main salience is weighted by its people, building a friendly workplace environment enhances a transparent relationship encompasses with flexibility and stabilization (Choo, 2013; Moayedi and Vaseghi, 2016). This research, presents a literature review of two variables; talent management and organizational effectiveness, where the variables and their dimensions will be define and discuss. 


\section{Talent Management}

\subsection{Definition of Talent Management}

The talent management subject has been studied from multiple angles, where each industry perceived and understood it according to several criteria differently (Deery and Jago, 2015).The literature review of talent management has not set one absolute definition that explained unified talent management connotations. Therefore, every organization must not accept a prescribed definition, but must rather have the ability to tail its own grasp of talent management. Each need to hold its concept value with varying properties and degrees according to some specifications, such as the type of industry the organization operates in, and organizational priorities relevantly with human resource issues (Revis, 2008). One of the definitions considered talent management as the best human resources in an organization whom performance highly influence the organization's overall performance (Campbell and Hirsh, 2013), another definition of talent management that it is the human being's ability; which includes dexterity, proficiency, and skillfulness for improvement (D'Annunzio-Green, 2008). Attract, hire, and retain the best talented employees is the major rationale to have plausible performance system in human resource management (Canedo et al., 2017). Possessing a highly good workforce in any organization is considered as a fertile source of interest for all the workers and the beneficiaries (Deery and Jago, 2015).

Many researchers have proposed models for developing talent management approaches that clarify the best means for gaining a solid competitive advantage through having a well-skilled, highly-experienced, and a talented staff of employees, suggesting that employees will achieve different performances among each other attributed to their different soft criteria. With that given, the business world has witnessed a big shift from a commodity-based economy into a knowledge-based economy, which leads organizations to alter both their structures and strategic options (Brown et al., 2003). The talent management notion has been evolved into substantial managerial basics by being not only centered on the traditional human resource practices like recruiting, but with much deeper grasp aimed at attracting, keeping, developing, and transitioning the talented staff (D'Annunzio-Green, 2008).A new direction in talent management has been provided recently by Hamilton and Davison(2018), as an illustration, this is an internal continuous approach to talent management where it will work by: identify area where knowledge stars (talented employees) add most value, promote the feedback and referrals before announcing for a new job, develop innovative ways in finding talent employees such as building strong relationships with educated institutions, labor unions, and finally, creating social capital with current employees as online communities where employees can share their experts and communicate with outsiders regarding decision making, as a result, this could shortening the future search and hiring process as well it will build trust relationship between organization and its employees which accordingly will gain the organization a plausible reputation as a merit firm to join.

\subsection{Dimensions of Talent Management}

Talent management is the implementation of integrated strategies designed to elevate the workforce productivity by creating improved processes for attracting, retaining, and developing, and training people to acquire the required skills and aptitude to meet current and future business needs. Researchers have developed multiple models to 
measure talent management, for example, (Abadi et al., 2013). Talent is considered as the primary driver of any successful company. It's become increasingly clear to most business owners and executive teams that, rather than being constrained by capital, companies are typically most constrained by talent, corporation have to learn that, relying on what business strategy it has, and what challenges it might face, at any given time it need the right talent to execute that strategy or deal with that challenge (Nazari et al., 2014).

In a strategic context, talent management originates from the strategic management of talents that flows in the organization and its main goal is to provide an accessible source of talents to link the right individuals with the right job positions at the right time, based on the strategic drivers of the business (Rastgoo, 2016). Talent management must be understood in the context of the firm's strategic capability, it has a potential to add value by improved strategy, thus strategic capabilities stand with talent management in order to affect the firm's financial performance (Joyceand Slocum, 2012). Moreover, talent management is the additional management processes and opportunities that are made available to people in the organization who are considered to be 'talent' (Ashridge Consulting, 2007).As a planning tool for human resource management, talent management looks very similar to workforce planning, while in the later, the HR personnel will experience a real opportunity of contributing to the organization in the sense of the quality of implementation supporting the plan. Advanced effort by four hospitals in Denmark has worked to develop a "Talent Management Pool" to deal with shortage in talented employees by cooperative with competitors, this pool helps in exchange employees, attract and retain more and better talent, and reduce cost of hiring external personal (Broeket al., 2018). A paper for Al-lozi et al. (2018) indicated that the strategy for attracting, developing and retention talents have a positive on the effectiveness of human resource information system in commercial banks.

In this paper, talent management variable will be is explained by suggesting that it has three different dimensions; to attract, to maintain, and to develop the talents (Nobarieidishe et al., 2014 and Nazari et al., 2014) this definition helps to configure out how talent management could be acquired to gain a competitive edge in simple and smooth steps.

\subsubsection{Talent Attraction}

According to (Ferreiraa et al., 2012), talent management is the implementation of integrated strategies designed to raise employees' productivity by developing processes for attracting, developing, retaining, and utilizing people with the required skills and aptitude to meet the current and the future business needs. Attracting and retaining top talents is a major concern for human capital management practitioners' today. Tracking talents and attracting them must be integrated with the management's overall strategies. Meanwhile, most of the organizations are not able to attract the talented individuals as new members, this lack of talents is the main obstacle in their way towards growth, and the compensation of this lack is a kind of major strategic advantage (Beheshtifar et al., 2012). 
The need for having a talent attraction program that plays as a marketing plan to visualize the current opportunity in an appropriate manner in a way that best offers what the business organization will provide to pull and catch the desired talents such as wages, benefits, and the growth opportunities (D'Annunzio-Green, 2008). Remuneration plays a significant role in attracting knowledgeable people, and the best way to attract such a valuable asset is by following what is called "employer branding."This type of branding implies showing the organizational endeavor in building a strong and unique image about it and installing this image in the minds of its employees to keep them and in the minds of the desired talented candidates to attract them (Hung, 2013).

Success on boarding of new talents is an integral aspect of any talent management strategy, with the high cost of attracting talent, business leaders must realize that effective integration of new hires into the organization is an important step to guarantee their success (Fapohunda, 2014).Talent attraction programs are designed to provide the organization with the desired talent pool that is aligned with the organizational strategy, which plays a crucial role in gauging employee's potential and adding a rigor structure for employee's future performance (Lepak and Shaw, 2008).Robust and progressive talent attraction programs will better help the organization to comprise the right people in the right place at the right time (Collings and Mellahi, 2009), Identifying and attracting competent talents help companies choose people who not only possess the required skills; but also exhibit the attitude, personality traits, and behavior that ensure organizational fit and promote commitment. After determining requirements of an organization, high-performance companies develop a profile of the ideal candidate, aiming at hiring only the top 10 to 15 percent of the available talent (Hale et al., 1998). When a selection process starts, success factors identified previously for a job can help as a basis for an interviewing strategy to assess the candidate's organizational fit. Another strategy that can be used to determine a level of success is to integrate behavioral-based questions that are designed to extract examples from candidates about their work history and the way they behaved in previous job situations. The third significant strategy of ensuring the best fit is through competency-based management, which can be described as the organization's understanding and perception of its needs and requirements (AbulMohaimen, 2013).

\subsubsection{Talent Maintenance}

The human resource management should have a clear vision in order to retain its current talents. This can be achieved through conducting continuous trainings for employees, and ensuring the good understanding of their needs and desires in order to keep them away from the other rivals sight (Abadi et al., 2013), depending on top management side by side with employees' empowerment used as an operative instrument for enhancing decision making skillfulness and expertise which pours in the interest of an employee's performance (Awamleh, 2013). Employees believed that in return of their submitted efforts and commitment, the organization shall help them promote their career path, which shall raise the employees' effectiveness and the overall organizational effectiveness accordingly; this intent is more obvious in service-providing organizations where there is a great reliance on the quality of the service (Revis, 2008). 
Employ retention has an effect on organization's success (Asrar et al., 2018). To guarantee effective leadership for the future, organizations endeavor to attract and retain top talent (Govaerts et al., 2011). Meanwhile, a top talent is difficult to find and expensive to replace, retaining and holding on skilled employees once they are on board is a major challenge. Moreover, departing employees often take with them valuable knowledge and expertise, and good relations with clients (Mitchell et al., 2001). The loss of a top talent to a competitor can diminish the organization's competitive advantage as well. Thus, to attract, engage, develop, and retain talent, those who have responsibility for talent management must understand what is important to employees. Rastgoo (2016) pointed out that reward is a mean to maintain employees and it leads to job satisfaction. Employee engagement is considered a key contributor to the retention of talent (Glen, 2006; Al Azmi et al., 2012). This area in which the lead has been taken by practitioners such as (Brooks, 2008) and (Baumruk, 2006), while rigorous academic research is required according to (Shuck and Wollard, 2008).

In developing countries, salary incentives, housing, and job rotation opportunities have been identified as good talent maintenance methods (Kabene, et al., 2006). Motivation can be regarded as the necessary drive for talent maintenance. Two types of motivation are commonly discussed, the intrinsic motivation and the extrinsic motivation. The intrinsic motivation is the internal driver, while the extrinsic motivation is an environmental incentive, reward, and challenges. Intrinsic motivation means that a person is engaged in any activity for its own sake, because it is satisfying and no reward is expected or requested. When an employee has a high intrinsic motivation, his feelings are closely relative to how well he or she performs. To motivate the talent, the intrinsic motivation such as career planning and development is one of the effective factors. To maintain talent, an alignment should be found between individual career planning and aspirations and the organization's career management processes, by doing so, we achieve an optimal match between individual and organizational needs (AbulMohaimen, 2013).

\subsubsection{Talent Development}

A process for assuring the consistency of talented employees' performance levels must be performed by doing an elaborated appraisal element for a higher job position issues and measuring the talent's degree of evolution (Abadi et al., 2013).Organizations must be fully committed to the right talent management strategies as part of the corporate's modality; in order to catch smart employees and top expertise, turning them into talented managers and leaders. One of the major responsibilities of an organization is to create a clear career path to attach the talent with the future needs (Nobarieidishe et al., 2014). When the management is concerned about the interests of its employee, coupled with the organization's interest, employees will be motivated in the development phase, favorably with certain practices, which will boost employee's professional development and involvement (Thunnissen, 2016). In an interview with (Janice Caplan, 2014), the author of Strategic Talent Development book, he stated that when management takes advantage of the employee engagement as an approach to talent development, by adopting the idea of focusing on the whole workforce engaging and developing not only outside the organization, but also inside it; that will be considered as a strategic 
application of talent management that depends on high possibilities and distinctive leadership. Talent development starts with a performance appraisal and evaluation, by which an individual's strengths and weaknesses are assessed and training needs are pinned down, providing the needed feedback for learning programs and career planning. In many organizations, the link between identifying the training needs and fulfilling them gets broken, which eventually may lead to unnecessary talent acquisition in the future. Similarly, succession planning tends to be approached from a blinkered perspective, with many organizations primarily focusing on senior management. While effective succession planning isn't merely about what occurs next in the boardroom; it's about identifying which roles are critical to the organization, regardless of seniority. Most organizations have multiple key person dependencies at even relatively junior levels, from an account manager who has developed a solid personal relationship with a key client, to specialist staff who understand the intricacies of individual systems and processes. Through identifying critical roles and mapping potential successors, organizations can guarantee that they tailor their employee development and talent management to meet business priorities (Ajaz, 2014). When human capital is both valuable and unique, firms are more likely to employ people internally, especially when their skills are firm specific. In these conditions, firms have both financial and strategic incentives to develop employees internally.

In addition, internal development of human capital helps firms realize the advantages of these employees in terms of their value-creating potential. Due to the fact that employees in this skill group possess abilities that are both valuable and unique, they are seen as core employees, who may serve as a source of competitive advantage (Barney, 1991). There are needs to be proper learning and development endeavors to aid employees in their career path. An organization extends both formal and informal interventions such as conventional training and development programs to creative alternatives such as talent coaching and mobility (Lifvergren et al., 2011). Training and development of talent are perceived as an important strategy in talent management.

A study conducted by (Haleet al., 1998) listed training and development on top of the five most effective retention strategies. Employees are more committed to employers who are more concerned with their employees' long-term career development (Dessler, 1999). A rationale behind this perception is that employees come to organizations with certain needs, desires, skills, and so forth, and expect to find a supporting work environment where they can utilize their abilities and satisfy many of their basic needs. Therefore, failing to fulfill these basic needs, the commitment level tends to diminish and it elevates the probability of the employees choosing to leave an organization. Moreover, coaching is also one aspect of talent development that can motivate talents effectively. Since the organization's success e talent knowledge of its people, they must develop current and future leaders (Bloch, 1995). Coaching has major benefits for both individuals and organizations. The potential implication for an organization that successfully employs an effective mentoring and coaching strategy includes increased employee retention and satisfaction, improved motivation, commitment and respect enhanced organizational performance, communication, and team effectiveness, and leveraged learning at lower costs. Canedo et al. (2017) suggested that human resource 
professionals need to be trained and educated about values, issues and preferred work environment to align with talent management strategies.

Organizations that aim at accomplishing a sustained competitive advantage must optimize their resources, in particular, human resources (Joyce and Slocum, 2012). In this regard, the management of people who are considered to be talented has been often proposed as the decisive factor for gaining a competitive advantage through people (Collings and Mellahi, 2009; Heinen and O'Neill, 2004). Traditionally, talent management has been focused on development of talents exclusively, meaning that it was directed towards a small percentage of the workforce who performed better than the rest, or displayed more "leadership" potential (Lewis and Heckman, 2006; Swailes, 2013). Exclusive talent-management approaches face two central challenges that are unlikely to dissolve in the near future. The first issue is the global scarcity of talent, where talent can be defined according to exclusive philosophies (Schuler et al., 2011), and the second issue is related to the highly dynamic environment organizations work in, which hinders the prediction of future talent needs (Yost and Chang, 2009).

\subsection{Organizational Effectiveness}

\subsubsection{Definition of Organizational Effectiveness}

Many researchers try to clarify the organizational effectiveness concept mostly in all fields of studies; since it is a prominent concept used to measure the overall organization's abilities starting from processing the available resources in order to make the desired output (Ashraf and AbdKadir, 2012). Many studies attributed the term organizational effectiveness interchangeably with an organizational performance that could be measured by many indexes such as the organizational profitability, financial market, stakeholders' satisfaction and the quality status (Henri, 2003; Crook et al., 2011; Sejjaaka and Kaawaase, 2014).

Organizational effectiveness is defined as the organization's success in attaining the desired goals via formulating its available resources to the fullest (Herman and Renz, 2008). The impact of achieving organizational effectiveness can be obvious by desired the patient's outcomes (An et al., 2011). According to (Rahman, 2014), the human resource is the most precious resource an organization could attain. Human resource can provide a strong base to create a prime organizational productivity, or organizational effectiveness, and a continued success for the long run. Some researchers suggested that the chosen managerial leadership style in the institution plays a major role in determining the certain set of conducts and behaviors, which have been followed by the leaders each according to his position. Thus, the employees in low levels of hierarchy will be influenced by these selected conducts and behaviors, and the organizational effectiveness and its continuity will be highly affected in turn by them either positively no negatively (Erkutlu, 2008).

Finally, Aydin and Ceylan (2009) in their study stated that when organizations start to utilize the behavioral knowledge and expertise to enhance its organizational development process, then the organizational effectiveness will be directly influenced by any development in a positive way. In the state of art, organizational effectiveness has 
been examined via various frameworks starting from the goal model which focuses on the final objectives and targets, the system model that deals with inputs, transformation process, and output, and the strategic constituencies' model that focuses on the stakeholder's mutual relationships with the intended organization (Henri, 2003). An et al.(2011) in a study of a group of nurses working in a Korean university hospital, assessed organizational effectiveness in terms of two dimensions; job satisfaction and organizational involvement.

\subsubsection{Organizational Effectiveness Dimensions}

Job satisfaction and organizational involvement are considered as essential factors in determining employees' contribution in the organization and the importance of their work.

\subsubsection{Job Satisfaction}

Throughout the history of organizational and behavioral research, the subject of employee satisfaction has been an interesting widespread empirical examination, resulting in a number of definitions. Employee satisfaction defined as the effective orientation that an employee has towards his or her work. It may also be recognized as the individual's perception and evaluation of the overall work environment (Sempane et al., 2002). On the other hand, Vukonjanski and Nikolić (2013) defined employee satisfaction as a global feeling about one's work or a related cluster of attitudes about various facets of the work environment. Employee satisfaction perceived as a 'positive emotional state resulting from the appraisal of one's job or job experiences' (Islam and Siengthai, 2009). A common aspect that connects these definitions is that employee satisfaction is concerned with what people in an organization feel about their overall work. Job satisfaction influences the organizational performance, employees behavior and sure their well-being, thus, improving job satisfaction, employee retention and reduce turnover occur by developing the employees competencies (Marques et al., 2018).

A study conducted by (Ellickson and Logsdon, 2001) emphasized that environmental factors and personal characteristics as the two most controlling variables that condition the level of employee satisfaction. Lambert et al. (2003) also found low employee satisfaction levels amongst employees whose expectations fell short. In public universities; a positive relationship between retaining talent and job satisfaction appeared, the same results were found for developing talent (Kamal and Lukman, 2017a, 2017b). For most management scholars, meeting the needs of employees remains the prime employee-satisfaction enhancement strategy (Giannikis and Mihail, 2011). Noting that job satisfaction is vital because a satisfied employee is more willing and able to perform and produce, and shows a higher level of productivity in comparison to dissatisfied ones (Sejjaaka and Kaawaase, 2014).

\subsubsection{Organizational Involvement}

Wood and Ogbonnaya (2016) in their recent study defined the organizational involvement as the management way focuses on enriching the productive performance of the organization, which depends on the degree of employee's awareness. Related the 
organizational involvement produced a good interaction among employees, boost their understanding of their organization's needs, and create a solid linkage with the entity vision, beliefs, and norms could double the productivity of those volunteering employees (Wang and Ashcraft, 2013).Self-managed teams, cross-training, shared information, participative decision making, and incentive rewards are manifestations of high employee involvement in organizations. Large numbers of manufacturing and service employees today are organized into teams, quality circles, or a "factory within a factory" that provides some degree of decision-making authority.

One crucial way to decrease resistance and promote support from supervisors is by illustrating the benefits for managers and providing them with a compelling explanation of a high involvement system. That means explaining the logic of the cause and effect between the involvement practices and organizational performance in a way that is relevant to their role and belief about the organization (Sonenshein and Dholakia, 2012). Indeed the essence of involvement is based on respecting that employees have a real stake in the consequences of decisions, involving the direction of their work unit and giving them a say in what happens. The psychology behind the benefits of involving employees in work processes and decision-making processes is based on alleviating the sense of uncertainty and fear that is common in such situations. Further; participation can increase employee resources for adapting to change and pressure by enhancing their sense of control over their work situation during stressful phases (Sharabati et al., 2010).

\section{Conclusion}

Employees are considered as the heart of any organization, due to their important role in the right implementation of the organization's strategies and policies, in addition to the impact of their integrated capabilities, skills, and creativity to achieve the ultimate goals (Kateb et al., 2015; Sikora et al., 2016). Therefore, organizations must make the right strategic decisions in accordance with the appropriate human resource qualitative manners, thus this leads to a higher organizational strategic position via having a competitive advantage, or even a core competency that gives the organization a potential of sustainable success (Shannak and Obeidat, 2012; Masa'deh et al., 2013a, 2013b; Obeidat et al., 2013; Kantardjieva, 2015). Organizations need to restructure their cultural platforms in a way that provides a wider capacity to absorb and nurture the besttalented employees; which highly relies on what is called communication (Tiwari, 2014).

With today's ever-changing business environment globally; that steers organizations and pushes them to excel their performance by modifying and optimizing their organizational assets, human resource is considered as the fundamental asset in any organization. Meanwhile, attracting and sustaining well-qualified and skillful staff of employees remains one of the struggles faced by organizations while attempting to ride the wave of change in the competitive business world (Collings, 2012). Tollman et al. (2016) stated that the overall organizational performance depends on the demeanor of its human resource. Thus, in order to leverage the organizational effectiveness, the focus shall be on harmonizing the human resource demeanor to be come in more harmony with the overall organizational context. 
In a study by (Myron and White, 2016) in their dissertation mentioned that; in the current business environment, organizations aspire to maintain a steady, balanced performance by the available human resources, which is necessary to preserve a constant excellence. Meanwhile, most organizations have many opinions and little logic or data to support their identification of their pivotal talent pool. In addition, the task of sustaining balance becomes harder as the definition of an organization's success changes from a strictly financial definition to become more defined by "sustainability". Studying the relationship between talent management and organizational effectiveness has received high attention and showed huge significance due to the continual changes in the business inputs demand and challenges (Ellström, 2012). Maximizing the effectiveness of human resource within an organization is a main goal in the industrial sector and for the corporation life-cycle requirements; thus investing in the human resource assets will enhance the employees' performance level which will be reflected on the whole organizational performance (Crook et al., 2011).Considering the fundamental role of the human resource management practices on creating a significant contribution to the organization's effectiveness is a very important instrument to be adopted and employed by the management during the policy making process (Schuler and Jackson, 2014). The future of talent management is expected to be too expensive and risky for small organizations (Broek et al. 2018). At the end it's important to mention that a talent paradox phenomenon occurs when talent may produce both empowerment and powerlessness simultaneously.

\section{References}

Abadi, M., Khadem, S., and Sadeghnia, A.(2013). Talent Management and Maintaining Talented Human Resource: A Case Study in Kashan University of Medical Sciences. European Online Journal of Natural and Social Sciences, 2(3), 3446-3457.

AbulMohaimen, M. (2013). Talent Management: Three New Perceptions Intended for Managing and Retaining Talents in Bangladesh.Asian Business Review, 3(5), 7-15.

Ajaz, K. (2014).The Changing Dynamics of Talent Acquisition: An Analysis of Recruitment Trends, Marketing Strategies, and Emerging Software and Services. Academ Arena, 6(4), 67-73.

Al Azmi, N., Al-Lozi, M., Al-Zu'bi, Z., Dahiyat, S., and Masa'deh, R. (2012). Patients Attitudes toward Service Quality and its Impact on their Satisfaction in Physical Therapy in KSA Hospitals. European Journal of Social Sciences, 34(2), 300-314.

Al-lozi, M. S., Almomani, R. Z. Q., and Al-hawary, S. I. S. (2018). Talent Management Strategies as a Critical Success Factor for Effectiveness of Human Resources Information Systems in Commercial Banks Working in Jordan. Global Journal of Management and Business Research: A Administration and Management, 18(1), 30-43. 
An, J., Yom, Y.,and Ruggiero, J. (2011). Organizational Culture, Quality of Work Life, and Organizational Effectiveness in Korean University Hospitals. Journal of Transcultural Nursing, 22(1), 22-30.

Ashraf, G., andAbdKadir, S. (2012). A Review on the Models of Organizational Effectiveness: A Look at Cameron's Model in Higher Education. Journal of International Education Studies, 5(2), 80-87.

Ashridge Consulting. (2007). Talent Management: Maximizing Talent for Business Performance, Chartered Institute of Management. www.ashridge.org.uk.

Asrar, Z., Azhar, T., and Hussain, M. (2018). Effect of Talent Management On The Success Of Organization Development. Archives of Business Research, 6(3), 90-103.

Awamleh, N. (2013). Enhancing Employees Performance via Empowerment: A Field Survey. Asian Journal of Business Management, 5(3), 313-319.

Aydin, B.,andCeylan, A. (2009).Does Organizational Learning Capacity Impact on Organizational Effectiveness? Research Analysis of the Metal Industry.Development and Learning Organizations, 23(3), 21-23.

Barney, J. (1991). Firms Resources and Sustained Competitive Advantage.Journal of Management, 17(1), 99-120.

Baumruk, R. (2006). Why Managers are Crucial to Increasing Engagement, Melcrum Publishing Ltd, www.melcrum.com.

Beheshtifar, M., Nasab, H., and Moghadam, M. (2012), Effective Talent Management: A Vital Strategy to Organizational Success. International Journal of Academic Research in Business and Social Sciences, 2(12), 227-234.

Bloch, S. (1995). Coaching Tomorrow's Top Managers. Executives Development, 8(5), 2022.

Brewster, C., and Suutari, V. (2005). Global HRM: Aspects of a Research Agenda. Personnel Review, 34(1), 5-21.

Broek, J. Van Den, Boselie, P., and Paauwe, J. (2018). Cooperative Innovation through a Talent Management Pool: A Qualitative Study on Coopetition in Healthcare. European Management Journal, 36(1), 135-144.

Brooks, W. (2008). Engagement by Design, Hemsley Fraser Group Limited, St James Court 74-94 Fore Street Saltash, Plymouth PL12 6JW.

Brown, P., Hesketh, A., and Williams, S. (2003). Employability in a Knowledge-Driven Economy. Journal of Education and Work, 16(2), 107-126. 
Canedo, J. C., Graen, G., and Grace, M. (2017). Let' s Make Performance Management Work for New Hires: They are the Future. Organizational Dynamics, (26 November). 1-5.

Chamorro-premuzic, T., Akhtar, R., Winsborough, D., and Sherman, R. A. (2017). The Datafication of Talent: How Technology is Advancing the Science of Human Potential at Work. COBEHA, 18(June), 13-16.

Campbell, V., and Hirsh, W. (2013). Talent Management: A Four Step Approach. Institute for Employment Studies (IES), Sovereign House, Church Street, Brighton BN1, 1UJ, UK.

Choo, C.W. (2013). Information Culture and Organizational Effectiveness. International Journal of Information Management, 33, 775-779.

Collings, D.G.,and Mellahi, K. (2009). Strategic Talent Management: A Review and Research Agenda.Human Resource Management Review, 19(4), 304-313.

Collings, V. (2012). Talent Management Decision Making. Management Decision, 50(5), 925-941.

Crook, T.,Todd, S., Combs, J., and Woehr, D. (2011). Does Human Capital Matter? A Meta-Analysis of the Relationship between Human Capital and Firm Performance. Journal of Applied Psychology, 96(3), 443- 456.

D'Annunzio-Green, N. (2008). Managing the Talent Management Pipeline. International Journal of Contemporary Hospitality Management, 20(7), 807- 819.

Deery, M., and Jago, L. (2015). Revisiting Talent Management, Work-Life Balance and Retention Strategies. International Journal of Contemporary Hospitality Management, 27(3), 453-472.

Dessler, G. (1999). How to Earn your Employees' Commitment. Academy of Management Executives, 13(2), 58-67.

Ellickson, M., and Logsdon, K. (2001). Determinants of Job Satisfaction of Municipal Government Employees. State and Local Government Review, 33(3), 173-184.

Ellström, S. (2012). Employability and Talent Management: Challenges for HRD Practices. European Journal of Training and Development, 36(1), 26-45.

Erkutlu, H. (2008).The Impact of Transformational Leadership on Organizational and Leadership Effectiveness-The Turkish Case. Journal of Management Development, 27(7), 708-726.

Fapohunda, T. (2014). Increasing Organizational Effectiveness through Better Talent Management. Research Journal of Human Resource, 2(4). 
Fegley, S. (2006).Talent Management Survey Report, Society for Human Resource Management (SHRM), 1800 Duke Street, Alexandria, VA 22314, USA.

Ferreiraa, P., Neirab, I., and Vieirac, E. (2012). The Strategic Approach to the HighPerformance Paradigm: A European Perspective. Social and Behavioral Sciences, 58, 474482.

Fogarassy, C., Szabo, K., and Poor, J. (2017). Critical Issues of Human Resource Planning, Performance Evaluation and Long-Term Development on the Central Region and NonCentral Areas: Hungarian Case Study for Investors. International Journal of Engineering Business Management, 9, 1-9.

Giannikis, S., and Mihail, D. (2011). Modelling Job Satisfaction in Low-Level Jobs: Differences between Full-Time and Part-Time Employees in the Greek Retail Sector. European Management Journal, 29(2), 129-143.

Glen, C. (2006). Key Skills Retention and Motivation: The War for Talent Still Rages and Retention is the High Ground, 38(1), 37-45.

Govaerts, N., Kyndt, E., Dochy, F., and Beart, H. (2011). Influence of Learning and Working Climate on the Retention of Talented Employees. Journal of Workplace Learning, 23(1), 35-55.

Hale, A., Heming, B., Smit, K., Rodenburg, F., andvan Leeuwen, N. (1998). Evaluating Safety in the Management of Maintenance Activities in the Chemical Process Industry. Safety Science, 28(1), 21- 44.

Hamilton, R., and Davison, H. K. (2018). The Search for Skills: Knowledge Stars and Innovation in the Hiring Process. Business Horizons, (1 February), 1-11.

Heinen, J., and O'Neill, C. (2004). Managing Talent to Maximize Performance. Employment Relations Today, 31(2), 67-82.

Herman, R., and Renz, D. (2008). Advancing Nonprofit Organizational Effectiveness Research and Theory: Nine Theses. Nonprofit Management and Leadership, 18(4), 399415.

Henri, J. (2003). Performance Measurements and Organizational Effectiveness: Bridging the Gap. Managerial Finance, 30(6), 93-123.

Hung, A. (2013). Understanding Talent Attraction: Perceived Attractiveness of Financial Reward Elements. A Master dissertation of Commerce in Organisational Psychology, Faculty of Commerce University of Cape Town. 
Islam, M., and Siengthai, S. (2009).Quality of Work Life and Organizational Performance: Empirical Evidence from Dhaka Export Processing Zone. Proceeding of ILO Conference on Regulating for Decent Work, Geneva: International Labour Office.

Joyce, W., and Slocum, J. (2012). Top Management Talent, Strategic Capabilities, and Firm Performance. Organizational Dynamics, 41, 183-193.

Kabene, S., Orchard, C., Howard, J., Soriano, M., and Leduc, R. (2006). The Importance of Human Resources Management in Health Care: A Global Context. Human Resources for Health, 4 (20).

Kamal, M. Y., and Lukman, Z. M. (2017a). The Influence of Talent Management Practices on Job Satisfaction. International Journal of Academic Research in Business and Social Sciences, 7(7), 859-864.

Kamal, M. Y., and Lukman, Z. M. (2017b). The Relationship between Retaining Talent and Job Satisfaction in Selected Public Universities. International Journal of Research in Business, Management and Accounting, 3(6), 21-25.

Kantardjieva, M. (2015). The Relationship between Total Quality Management (TQM) and Strategic Management. Journal of Economics, Business and Management, 3(5), 537-541.

Kateb, M., Swies, R., Obeidat, B., and Maqableh, M. (2015). An Investigation on the Critical Factors of Information System Implementation in Jordanian Information Technology Companies. European Journal of Business and Management, 7(36), 11-28.

Lambert, P., Millimet, D., and Slottje, D. (2003). Inequality Aversion and the Natural Rate of Subjective Inequality. Journal of Public Economics, 87, 1061-1090.

Lepak, D., and Shaw, J. (2008). Strategic HRM in North America: Looking to the Future. International Journal of Human Resource Management, 19, 1486-1499.

Lewis, R., and Heckman, R. (2006). Talent Management: A Critical Review. Human Resource Management Review, 16, 139-154.

Lifvergren, S., Docherty, P., and Shani, A. (2011).Chapter 4 Towards A Sustainable Healthcare System: Transformation through Participation, in Susan Albers Mohrman, Abraham B. (Rami) Shani (ed.) Organizing for Sustainability (Organizing for Sustainable Effectiveness), Emerald Group Publishing Limited, (1), 99-125.

Marques, C. P., Leal, C. T., Marques, C. S., and Cabral, B. F. T. (2018). Internal Marketing and Job Satisfaction in Hotels in Via Costeira, Natal, Brazil. Tourism and Management Studies,14(S/1), 36-42.

Masa'deh, R., Gharaibeh, A., Maqableh, M., and Karajeh, H. (2013a). An Empirical Study of Antecedents and Outcomes of Knowledge Sharing Capability in Jordanian 
Telecommunication Firms: A Structural Equation Modeling Approach. Life Science Journal, 10(4), 2284-2296.

Masa'deh, R., Shannak, R., and Maqableh, M. (2013b). A Structural Equation Modeling Approach for Determining Antecedents and Outcomes of Students' Attitude toward Mobile Commerce Adoption. Life Science Journal, 10(4), 2321-2333.

Mathew, A. (2015). Talent Management Practices in Select Organizations in India.Global Business Review, 16(1), 137-150.

Mitchell, T., Holtom, B., Lee, T., Sablynski, C., and Erez, M. (2001). Why People Stay: Using Job Embeddedness to Predict Voluntary Turnover. Academy of Management Journal, 44, 1102-1122.

Moayedi, Z., and Vaseghi, M. (2016). The Effect of Talent Management on Organizational Success. Scinzer Journal of Accounting and Management, 2(3), 16-20.

Mohrman, S., and Lawler III, E. (2014). Designing Organizations for Sustainable Effectiveness: A New Paradigm for Organizations and Academic Researchers. Journal of Organizational Effectiveness: People and Performance, 1(1), 14-34.

Myron, D.,andWhite, M. (2016).Examining Dynamic Leadership: A Mixed Methods Analysis of Organizational Effectiveness. Unpublished Doctoral Dissertation, University of North Carolina AandT State University.

Nazari, K., Akbari, P., and Veismoradi, A. (2014). Talent Management and Recruitment Strategies. Mediterranean Journal of Social Sciences, 5(20), 3085-3090.

Nobarieidishe, S., Chamanifard, R., and Nikpour, A. (2014). The Relationship between Talent Management and Organizational Commitment in International Division of Tejarat Bank, Iran. European Online Journal of Natural and Social Sciences, 3(4), 1116-1123.

Obeidat, B., El-Rimawi, S., Maqableh, M., and Al-Jarrah, I. (2013). Evaluating the Profitability of the Islamic Banks in Jordan. European Journal of Economics, Finance and Administrative Sciences, 56, 27-36.

Rahman, H. (2014). Training and Job Satisfaction for Organizational Effectiveness: A Case study from the Banking Sector. Journal of Central European Business Review, 3(4), 27-34.

Rastgoo, P. (2016). The Relationship of Talent Management and Organizational Development with Job Motivation of Employees. ActaUniversitatisAgriculturaeetSilviculturaeMendelianaeBrunensis, 64(2), 653-662.

Revis, B. (2008). Talent Management in Hospitality: Graduate Career Success and Strategies. International Journal of Contemporary Hospitality Management, 20(7), 781791. 
1.1 .1

Schuler, R., and Jackson, S. (2014). Human Resource Management and Organizational Effectiveness: Yesterday and Today. Journal of Organizational Effectiveness: People and Performance, 1(1), 35-55.

Schuler, R., Jackson S., and Tarique, I. (2011). Global Talent Management and Global Talent Challenges: Strategic Opportunities for IHRM. Journal of World Business, 46, 506516.

Shannak, R., and Obeidat, B. (2012). Culture and the Implementation Process of Strategic Decisions in, Jordan. Journal of Management Research, 4(4), 257-281. https://doi.org/10.5296/jmr.v4i4.2160

Sejjaaka, S., and Kaawaase, T. (2014). Professionalism, Rewards, Job Satisfaction and Organizational Commitment amongst Accounting Professionals in Uganda. Journal of Accounting in Emerging Economies, 4(2), 134-157.

1.1.2 Sempane, M., Rieger, H., and Roodt, G. (2002). Job Satisfaction in Relation to Organisational Culture. SA Journal of Industrial Psychology, 28(2), 23-30.

Sharabati, A., Jawad, S., and Bontis, N. (2010). Intellectual Capital and Business Performance in the Pharmaceutical Sector of Jordan. Management Decision, 48(1), 105131.

Shuck, M.,and Wollard, K. (2008). Employee Engagement: Motivating and Retaining with Tomorrow's Workforce (Perspectives on Practice).New Horizons in Adult education and Human Resource Development, 22(1), 48-53.

Sikora, D., Thompson, K., Russell, Z., and Ferris G. (2016), Reimagining over Qualified Human Resources to Promote Organizational Effectiveness and Competitive Advantage. Journal of Organizational Effectiveness: People and Performance, 3(1), 23-42.

Sonenshein, S., and Dholakia, U. (2012). Explaining Employee Engagement with Strategic Change Implementation: A Meaning-Making Approach. Organization Science, 23(1), 1-23.

Sumardi, R. (2014). Talent Management at Steelcase Manufacturing, Malaysia: Managing High Performance. Emerald Emerging Markets Case Studies, 4(6), 1-14.

Swailes, S. (2013). The Ethics of Talent Management. Business Ethics: A European Review, 22(1), 32-46.

Thunnissen, M. (2016). Talent Management. Employee Relations, 38(1), 57-72.

Thunnissen, M., and Buttiens, D. (2017). Talent Management in Public Sector Organizations: A Study on the Impact of Contextual Factors on the TM Approach in Flemish and Dutch Public Sector Organizations. Public Personnel Management,46(4), 
391-418.

Tiwari, S. (2014). Infosys Nurtures the Talent of Tomorrow. Human Resource Management International Digest, 22(6), 27-29.

Tollman, P., Panier, V., Dosik, D., Biondi, P., and Cuss, F. The Boston Consulting Group, Inc. (2016).Organizational Effectiveness: A Key to Rand Productivity, doi:10.1038/nrd.2016.91.

Vukonjanski, J., and Nikolić, M. (2013). Organizational Culture and Job Satisfaction-The Effects of Company's Ownership Structure. Journal of Engineering Management and Competitiveness (JEMC), 3(2), 41-49.

Wang, L., and Ashcraft, R. (2013). Organizational Commitment and Involvement: Explaining the Decision to Give to Associations. Nonprofit and Voluntary Sector Quarterly, 43(25), 615-835.

Wood, S., and Ogbonnaya, C. (2016). High-Involvement Management, Economic Recession, Well-Being, and Organizational Performance. Journal of Management, 15,

Yost, P., and Chang, G. (2009). Everyone is Equal, but Some Are More Equal than Others. Industrial and Organizational Psychology, 2, 442-445. 